Revue Française de Civilisation Britannique

Les Enjeux de l'interdisciplinarité en civilisation britannique

\title{
Review of A Crooked Line: from Cultural History to the History of Society by Geoff Eley
}

John Mullen

\section{(2) OpenEdition}

\section{Journals}

Electronic version

URL: http://journals.openedition.org/rfcb/3017

DOI: $10.4000 /$ rfcb.3017

ISSN: 2429-4373

Publisher

CRECIB - Centre de recherche et d'études en civilisation britannique

Electronic reference

John Mullen, "Review of A Crooked Line: from Cultural History to the History of Society by Geoff Eley », Revue Française de Civilisation Britannique [Online], XXIV-1 | 2019, Online since 22 March 2019, connection on 20 April 2019. URL : http://journals.openedition.org/rfcb/3017 ; DOI : 10.4000/ rfcb.3017

This text was automatically generated on 20 April 2019.

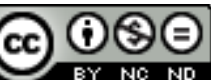

Revue française de civilisation britannique est mis à disposition selon les termes de la licence Creative Commons Attribution - Pas d'Utilisation Commerciale - Pas de Modification 4.0 International. 


\section{Review of A Crooked Line: from Cultural History to the History of Society by Geoff Eley}

John Mullen

\section{REFERENCES}

Geoff Eley, A Crooked Line: from Cultural History to the History of Society, University of Michigan Press, Anne Arbor, 2005

1 Although originally published more than a decade ago, this work remains tremendously useful today, and it seemed to us relevant to a journal issue centred around disciplines and methodology. In addition, the book is not so well-known in France.

2 It is in some ways a daunting piece of work: Geoff Eley takes up the challenge of recounting the main trends in historiography from the 1950s on: the consecutive rise and transformation of social history and then of cultural history, in a period where the number of professional historians increased massively, while the sources available and the tools at their disposal were ever richer. Along the way, he mentions many dozens of historians, and few readers can hope to be familiar with the work of more than a fraction of them in any detail.

3 The reason his attempt is important is that it sheds light on those old but ever-fresh questions: what do historians do, what should they do, and why? Eley tries to study, he says, how the past "gets worked into arresting images and coherent stories", "how it gets pulled and pummelled into reasons for acting" (p.9). His main conclusion is the importance of politics in its widest sense. What historians do, and what questions historians ask, depend both on the political situation they are living through, and on the group interests which are most important in their world view. Eley is particularly opposed to what he terms "Whiggish historiography" which claims that historians are 
simply getting better all the time, and the most recent works are therefore always the best ones to quote.

4 To help structure the story of History, Eley sets it to a semi-autobiographical plan. The main chapters, entitled "Becoming a historian", "Optimism: thinking like a Marxist", "Disappointment", "Reflectiveness" and "Defiance" take us through his career as a professional historian.

5 He began learning history in a most traditional manner at Oxford University, in the late 1960 s, as one of a series of working-class boys having managed to move up in society through the grammar schools. His early work was on German social history, and he was among those who insisted that Nazism did not interrupt history, but was part of it. That meant that social tensions, and indeed class struggle, could be found in different forms in Germany throughout the Nazi period of 1933-45.

6 His chapter on "thinking like a Marxist" recounts some of the work done by British Marxists and the central importance of reviews such as Past and Present (founded in 1952) and Social History. He notes that the creativity and rigour of historians such as Hobsbawm, Rudé, Samuel and Morton transformed history just at the point when the massive expansion of higher education meant that the number of working historians was increasing exponentially. The French annales school was highly influential in Britain too, in particular the works of Bloch on the "royal touch" and Braudel on the Mediterranean. Indeed, Eley insists that there was, in the 1950s at least, "no clear demarcation between Marxists and what was known as 'the French school"'.

7 In parallel with the rise in social movements which brought to the fore the politicization of questions which had previously been considered purely individual, such as the balance of power inside the family, or the daily micro-aggressions on non-white people in a racist society, cultural history, never completely defined, widened tremendously the types of object and event historians could study, while often maintaining the Marxist priority on considering the lives of ordinary people. In the late 1960s a series of new journals were formed (for example in 1970 the Journal of Interdisciplinary History), and then, in 1974, the first journal of Urban History. Tremendous steps forward had been made in the 1960s and 1970s, but Eley felt there was a real danger that the quantitative would take up far more space than it deserved. "Despite everything else the Cambridge group achieved during the $60 \mathrm{~s}$ and $70 \mathrm{~s}$, we learned little from them about the texture of 'family life and illicit love in earlier generations"'.

8 Good news came along, Eley maintains, in the form of a rising importance given to culture, despite much scepticism from established historians. "...in the British case", he writes, "many cultural historians initially found a home in cultural studies rather than history departments as such." While "among German historians, even in the mid-1990s, arguments for the new cultural history were still meeting angry or dismissive resistance". Eley lived this period fully and emotionally: "Unease crept up on us slowly, a gradual doubt in the sufficiency of social history's totalising claims."

9 From the "cultural materialism" brought in by Raymond Williams (while remaining close to Marxism) to the "linguistic turn" initially hinted at by Gareth Stedman Jones, a number of new initiatives of the 1970s and 1980s are highlighted. Britain remained a key site for historiographical renewal, although Eley also speaks of the work of German historians, such as that of the proponents of the "history of everyday life" (Alltagsgeschichte). 

category. Indeed, the rise of cultural history happened at the same time as women were gradually being allowed a small space among historians. ${ }^{1}$

Discursive analysis became central. According to Eley, "by restating the archive as a question, Foucault challenged historians to think about the very ground from which history could be written." This made more complex those ideas about agency and the construction of subjectivities which had often been little examined previously. As subjectivities became more important, biography rose in status, having been rejected by social historians in the previous period, who were reacting against the mass production of hagiography of Kings, Queens and heroes which one can still find in the bookshops. Psychoanalytical tools were now called upon to help write innovative biographies.

12 Eley explains that this move to discourse was not without its critics, as can be seen in such publications as Brian Palmer's 1990 work Descent into Discourse: The Reification of Language and the Writing of Social History (Temple University Press, Philadelphia). ${ }^{2}$ But Eley is firmly in the camp of the new wave here.

At the same time as these changes, the dialogue between history and anthropology was being reinforced, and this gave rise to a post-colonial critique of previous anthropologists, as the tools of anthropology were now to be applied to Western society and not just to the study of the Southern or Eastern "Other" from colonized spaces. The rise of "privilege theory" with such publications as The Wages of Whiteness by David Roediger in 1991 led to such areas as "subaltern studies" gaining resources and historians. Another key development was "the memory boom" which has seen commemoration and its analysis become fundamental vectors of a large-scale production of new history. The journal History and Memory was founded in 1989. The slow rise of oral history accompanied all this.

14 The leaving behind, in its old form, of social history inspired by Marxist method, seemed essential to Eley, though he does say there were some costs involved. The widest analytical questions about the industrialization of the entire world in the $20^{\text {th }}$ century, or about the transition from feudalism to capitalism, seem to have been abandoned, he says: no one is concerned with these any longer.

15 All in all the book recounts an exciting and impressive adventure based on the massive expansion in the amount of history produced, the tools chosen to craft it with and the number of questions historians ask.

In some ways, it is the Marxist historians, a current Eley used to identify with, who get the least generous treatment in the book. Escaping from "the tyranny of grand narratives" is celebrated, with little analysis of what Marxist historians may be doing these days, or of exactly which narratives were tyrannical. As a result, one can get the uneasy impression that he thinks there is only one kind of Marxism (the one linked with Russian and Eastern European dictatorships of the mid twentieth century), and this naturally makes the Marxist approach easier to reject. To give a more specific example, the "rejection" of a "base and superstructure" approach seems to be unquestioningly welcomed, without us finding out why such rejection was a wonderful thing, and again, one gets the impression that he thinks there was just the one, extremely unsophisticated, version of base and superstructure theory, which common sense had to do away with. ${ }^{3}$

17 A final notable element in the narrative is the surprisingly high temperature at which conflicts between different views of history seem to have been carried on at, according to

Revue Française de Civilisation Britannique, XXIV-1 | 2019 
Eley. He speaks of the time when Marxists could not get jobs in German universities, and of times when the conflicts between different schools of historians seemed filled with sound and fury. This fact also needs analysing. In reflecting on the history of history, we also need to try to have some understanding of the sources of these conflicts within the field of state-funded history. State-funded history, in our universities, is not closely statecontrolled in our democratic countries, but the structures of the discipline and the means of access to jobs and funding can be very influential in setting the historical agenda. This aspect - the material question of how history is produced and why - receives little space in Eley's book, but this is one of very few weaknesses in an important work.

\section{NOTES}

1. By 2010 , women made up $42 \%$ of new history $\mathrm{Ph}$ Ds in the United States, around $35 \%$ of University history lecturers, but only $18 \%$ of full professors. (Data from the American Historical Association)

2. And indeed in Alex Callinicos's Against Postmodernism, a Marxist Critique, (London, Polity, 1990).

3. Whereas the contributions of such writers as Terry Eagleton and Chris Harman might seem to point to the possibility of a more nuanced debate.See Chris Harman, "Base and Superstructure" in Chris Harman, Marxism and History, London, Bookmarks, 1998, pp. 7-54 ; Terry Eagleton, Base and Superstructure Revisited, New Literary History Vol. 31, No. 2, Spring, 2000, pp. 231-240

\section{AUTHORS}

JOHN MULLEN

Université de Rouen, ERIAC 